\title{
Implications of miR cluster 143/145 as universal anti-oncomiRs and their dysregulation during tumorigenesis
}

\author{
Ani V. Das* and Radhakrishna M. Pillai
}

\begin{abstract}
Tumorigenesis is a multistep process, de-regulated due to the imbalance of oncogenes as well as anti-oncogenes, resulting in disruption of tissue homeostasis. In many cases the effect of oncogenes and anti-oncogenes are mediated by various other molecules such as microRNAs. microRNAs are small non-coding RNAs established to posttranscriptionally regulate more than half of the protein coding genes. miR cluster 143/145 is one such cancer-related microRNA cluster which is down-regulated in most of the cancers and is able to hinder tumorigenesis by targeting tumor-associated genes. The fact that they could sensitize drug-resistant cancer cells by targeting multidrug resistant genes makes them potent tools to target cancer cells. Their low levels precede events which lead to cancer progression and therefore could be considered also as biomarkers to stage the disease. Interestingly, evidence suggests the existence of several in vivo mechanisms by which this cluster is differentially regulated at the molecular level to keep their levels low in cancer. In this review, we summarize the roles of miR cluster 143/145 in cancer, their potential prognostic applications and also their regulation during tumorigenesis.
\end{abstract}

Keywords: MicroRNAs, miR cluster 143/145, Anti-oncomiR, Multidrug resistance, Tumorigenesis

\section{Background}

Cancer is a complex condition arising from the accumulation of several genetic alterations privileged to deregulated cell division. Extensive research to unveil the molecular mechanisms of tumorigenesis led to the characterization of a large number of genes as oncogenes and anti-oncogenes. It was thought that alterations in these molecules are the reasons leading to cancerous growth until the involvement of microRNAs (miRNAs) was exposed. miRNAs are endogenous small (about 22 bp in length); non-coding, regulatory RNAs present in a wide variety of organisms and are located in the intronic or non-intronic regions of protein-coding genes transcribed either along with the genes or independently. miRNAs are transcribed as long primary RNAs by RNA polymerase II [1] which then undergo two steps of processing: first in the nucleus by the RNase III-type protein Drosha [2]

*Correspondence: anivdas@rgcb.res.in

Cancer Research Program-9, Rajiv Gandhi Centre for Biotechnology,

Thycaud.P.O., Thiruvananthapuram-14, Kerala, India and DGCR8 $[3,4]$ generating pre-miRNAs and second by Dicer, after exported to the cytoplasm by Exportin-5 or Exportin-1 [5], to produce mature miRNAs. Mature miRNAs then act as negative regulators of gene functions by becoming a part of the RNA-induced silencing complex (RISC) [1] and target their downstream mRNAs by basepairing to their complementary sequences mostly at the 3'UTR region which results in the degradation of target mRNAs and/or inhibition of translation, thereby decreasing the specific gene expression [6,7]. Most miRNAs are evolutionarily conserved and display diverse temporal and tissue-specific expression pattern [8-10]. A single miRNA can target and regulate more than hundreds of mRNAs, and one mRNA can be targeted by multiple miRNAs [11-13]. miRNAs contribute to a different level of molecular regulation, thus being involved in various roles in cellular and developmental functions, such as dorso-ventral axis and temporal pattern formation [14, $15]$, cell death and cell proliferation [16, 17], neuronal differentiation [18], stem cell proliferation and maintenance $[19,20]$ and also, in embryonic development [21]. 
Recently, miRNAs have gained tremendous attention in the field of cancer research. Altered miRNA expression can lead to cellular de-differentiation, oncogenesis, cancer metastasis and tumor invasion [22]. miRNA de-regulation is considered as a common hallmark of cancer [23], scoring miRNAs as important diagnostic and therapeutic targets. Calin et al. reported for the first time that two miRNAs, miR-15 and miR-16, were involved in the development of chronic lymphocytic leukemia [24] followed by $\mathrm{He}$ et al. who demonstrated that expression of miR-1792 cluster could enhance c-Myc-induced tumorigenesis marking this cluster to be the first potential non-coding oncogene, referred to as oncomiR-1 [25]. Likewise, let-7 family of miRNAs was reported to regulate expression of a proto-oncogene, the RAS protein [26, 27], and hence were coined as anti-oncomiRs. Later, many miRNAs have been reported to have roles in oncogenesis and miR cluster $143 / 145$ is one among them having anti-oncogenic effects in many cancers which are being discussed in this review in detail.

\section{miR cluster 143/145}

miR cluster 143/145 comprises of two miRNAs, miR-143 and miR-145, that have significant roles in various cellular functions and are co-expressed in a variety of cell types and tissues [28]. These miRNAs are transcribed from a putative cluster on chromosome 5 in human (5q33) and chromosome 18 in mouse (18qE1), and are conserved across species (Fig. 1). miR-143 is separated from miR-145 by $\sim 1.7 \mathrm{~kb}$ sequence [28]. Since they are in the same cluster and suggested to be transcribed together, it was speculated that they could be involved in similar functions. However, independent involvement of these miRNAs is also reported in many cellular processes. Both miR-143 and miR-145 are expressed in normal tissues in significant levels, with highest expression in colon and lowest in liver and brain [28]. The expression of these miRNAs was considerably high in prostate, cervix, stomach, uterus and small intestine and low in kidney, placenta, testis, spleen and skeletal muscle [28]. This cluster is found enriched in embryonic stem cells which differentiate into cardiac progenitors [29] suggesting an involvement in cardiac morphogenesis. They play a very important role in the fate specification of vascular smooth muscle cells since they target a number of transcription factors to inhibit proliferation in order to promote differentiation [29].

\section{miR cluster 143/145 in cancers}

miR-143 and miR-145 are now regarded as tumor suppressors since they target a number of genes involved in the tumorigenesis (Table 1), and their deregulation has been reported as one of the early events in cancer development [30, 31]. Both miR-143 and miR-145 are commonly seen down-regulated in a wide variety of cancer cell lines and tumors of the hematopoietic system, breast, lung, colon, prostate, the gastrointestinal system, ovary, cervix, head and neck, bladder [23, 32, 33], endocrine cancers such as thyroid, pituitary and gonads [34], germ-cell tumors (GCTs) [35], gallbladder cancer [36, 37], renal cell carcinoma [38-40], osteosarcoma [41, 42], and neuroblastoma [43, 44]. The reduced miR-145 expression in prostate cancer $(\mathrm{PCa})$ samples correlated with higher Gleason score, advanced stage, tumor size, higher prostate-specific antigen (PSA) and significantly shorter disease-free survival (DFS) for the PCa patients [45] and also associated with poor prognosis, lymph node metastasis and advanced stage in cervical cancers [46]. Low levels of miR-143 was negatively correlated with tumor size and lymph node metastasis in breast cancer while that of miR-145 was associated with dysplastic nodules, Hepatitis $\mathrm{C}$ virus-infection and metastasis in hepatocellular carcinoma (HCC) [47-49]. The observation that $\mathrm{ALDH}^{+\mathrm{ve}} / \mathrm{CD} 44^{+\mathrm{ve}}$ cancer stem cells showed low levels of miR-145 reinforced its importance as an effective approach to target the stem cell population in cancer [50]. Similar observations were made in case of glioma as well, where the decreased levels of miR cluster $143 / 145$ were positively correlated with poor prognosis and negatively correlated with ABCG2, suggesting that miR-145 could efficiently target stem cell-like populations and reduce the migration and invasion of such cells [51]. miR cluster $143 / 145$ has also been shown to play crucial role in the pathogenesis of $\mathrm{B}$ cell malignancies. It is suggested that miRNAs on chromosome $5 \mathrm{q}$ have an important role in leukemia and many of the miRNAs on the Chr:5q including miR-145 have been found to be deregulated in leukemia.

Very interestingly, a significant correlation of miR cluster 143/145 expression with environment-mediated cancer development was found in the case of lung cancer. Lung cancer is associated with environmental carcinogens such as cigarette, air pollution, and heavy metals. Chronic exposure of chromium [Cr(VI)], one such heavy metal widely used in industries, to non-tumorigenic human lung epithelial BEAS-2B cells resulted in the repression of miR-143 which in turn led to the malignant transformation, suggesting that the effect of environmental carcinogens could be mediated by miRNAs. Similarly, in malignant pleural mesothelioma (MPM), an aggressive cancer associated with long-term exposure to asbestos, miR cluster $143 / 145$ was found to be significantly down-regulated, suggesting that these miRNAs may serve as suitable biomarkers for distinguishing MPM from non-cancerous pleural tissues [52, 53]. Smoking, another cause for lung cancer, has also a negative 


\begin{abstract}
a

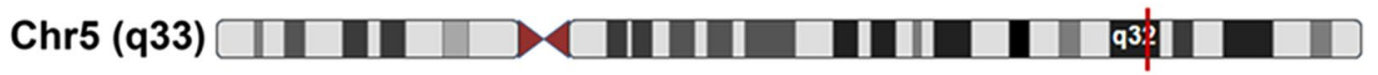

b

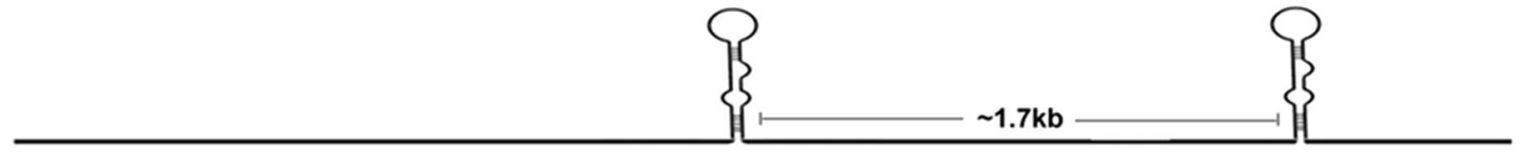

miR-143

miR-145
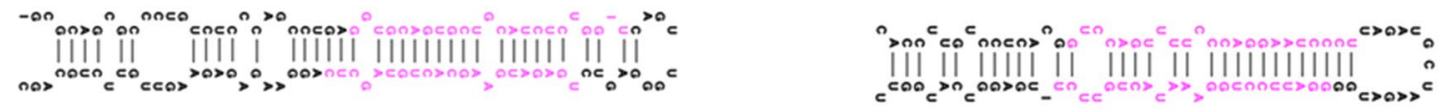

C

hsa-miR-143

Human CGCCCUGUCUCCCAGCCUGA GGUGCAGUGCUGCAUCUCUGGU CAGUUGGGAGUCUGAGAUGAAG CACUGUAGCUCAGGAAGAGAGAAGUUGUUCUGCAGC

Rhesus CGCCGUGUCUCCCAGCCUGAGGUGCAGUGCUGCAUCUCUGGU CAGUUGGGAGUCUGAGAUGAAGCACUGUAGCUCAGGAAGAGAGAAGUUGUUCUGC AGC

Chimpanzee CGCCCUGU CUCCCAGCCUGA GGUGCAGUGCUGCAUCUCUGGU CAGUUGGGAGUCUGAGAUGAAG CACUGUAGCUCAGGAAGAGAGAAGUUUUUCUGCAGC

Mouse --------CCUGA GGUGCAGUGCUGCAUCUCUGGU CAGUUGGGAGUCUGAGAUGAAG CACUGUAGCUCAGG---:-

Rat CGCC-UGUCUCCCAGCCUGAGGUGCAGUGCUGCAUCUCUGGU CAGUUGGGAGUCUGAGAUGAAGCACUGUAGCUCAGGAAGGAGAAGAUGUUCUGCAGC

Oppossum -------CCCGAGGUGCAGUGCUGCAUCUCUGGU CAGUUGUGAGUCUGAGAUGAAG CACUGUAGCUCGGG---

Xenopus -----UGUCUCCCAGCCCAA GGUGCAGUGCUGCAUCUCUGGU CAGUUGUGAGU CUGAGAUGAAG CACUGUAGCUCGGGAAGGGGAAU--:--:-

Pig -----GUCCCCCAGCCGGAGGUGCAGUGCU GCAUCUCUGGU CAGCUGGGAGUCUGAGAUGAAG CACUGUAGCUCGGGAAGGAGA --

Dog --1.--- GGUGCAGUGCUGCAUCUCUGGU CAGUUGGGAGUCUGAGAUGAAG CACUGUAGCUC --

Zebrafish UCUACAGUCGUCUGGCCCGCGGUGCAGUGCUGCAUCUCUGGU CAACUGGGAGUCUGAGAUGAAGCACUGUAGCUCGGGAGGACAACACUGUC--AGCUC-

d

hsa-miR-145

Human GUCCUCACGGUCCAGUUUUCCCAGGAAUCCCUUAGAUGCUAAGAUGGGGAUUCCUGGAAAUACUGUUCUUGAGGUCAUGGUU

Rhesus GUCCUCACGGUCCAGUUUUCCCAGGAAUCCCUUAAAUGCUAAGAUGGGGAUUCCUGGAAAUACU GUUCUUGAGGUCAUGGUU

Mouse GUCCUCACGGUCCAGUUUUCCCAGGAAUCCCUUAGAUGCUAAGAUGGGGAUUC CUGGAAAUACUGUUCUUGAGGU CAUGGUU

Rat ---CUCACGGUCCAGUUUUCCCAGGAAUCCCUUGGAUGCUAA GAUGGGGAUUC CUGGAAAUACU GUUCUUGAG--------

Oppossum GUCCUCACGGUCCAGUUUUC CCAGGAAUCCCUUGGAUGCUAA GAUGGGGAUUC CUGGAAAUACU GUUCUUGAGGU CAUGGCU

Xenopus ---CUCAGGGUCCAGUUUUCCCAGGAAUCCCUUAGAUGCUAAGAUGGGGAUUCCUGGAAAUACU GUUCUUGAG---------

Pig UUCCUCAAGGUCCAGUUUUCCCAGGAAUCCCUUGGGUGCUGUGGUGGGAUUCCUGGAAAUACUGUUCUUGGGGUGUAGGC-

Chimpanzee GUCCUCACGGUCCAGUUUUCCCAGGAAUCCCUUAGAUGCUGA GAUGGGGAUUCCUGGAAAUACU GUUCUUGAGGU CAUGG--

Dog GUCCUCACGGUCCAGUUUUCCCAGGAAUCCCUUAGAUGCUAAGAUGGGGAUUCCUGGAAAUACUGUUCUUGAGGUCAUGGUU

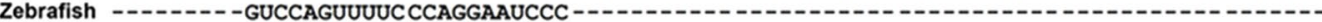

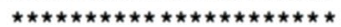

Fig. 1 miR cluster 143/145 is evolutionarily conserved across species. a Schematic of chromosomal location of miR cluster 143/145 (adapted from UCSC genome browser. b Schematic representation of structures of miR cluster 143/145 primary transcripts and their location. Multi-species alignment of sequences of miR-143 (c) and miR-145 (d) (courtesy to Clustal W Omega)
\end{abstract}

effect on miR cluster 143/145 expression. miR-145 was one of the mostly down-regulated miRNAs in cigarette smoke-exposed lungs of rodents [54]. Whether this effect could predict malignant transformation, needs further investigation.

\section{miR cluster $143 / 145$ and multidrug resistance}

Multidrug resistance is a phenomenon where cells develop resistance to a range of cytotoxic agents by effluxing them out with the help of transporter proteins. Though these transporter proteins, otherwise known as multidrug resistant proteins (MDR), are crucial for cell survival, their high expression in cancer cells has been a significant obstacle to successful chemotherapy. miR cluster 143/145 has been known to regulate MDRs in various cancers. miR-145 is reported to inhibit MDR1 in intestinal cells [55] and ABCG2 in glioma cells as we all as in corneal cells [56]. The reduction in miR-145 expression could be related to drug resistance potential of many cancer cells [57]. Reduced levels of miR-145 caused increase in the levels of Sp1 and CDK6 thereby reducing the levels of Pgp and $\mathrm{pRb}$, thus suggesting a possible the reason for increased chemoresistance in ovarian cancer cells [58]. Ectopic expression of miR-145 increased the sensitivity of cells to various drugs such as paclitaxel and adriamycin in cervical cancer [58], as well as vemurafenib [59], 5-FU, irinotecan and oxaliplatin $[60,61]$ in colorectal cancer. In glioblastoma cells, miR-145 could sensitize the cells to temozolomide as well as to irradiation [62]. Likewise, adenoviral mediated over-expression of miR-145 (Ad-miR-145) in breast cancer cells increased the sensitivity to 5 -FU in vitro and in vivo, suggesting that a combination of miR-145 with drugs like 5-FU could be a possible option to target 
Table 1 Validated targets for miR cluster 143/145 with their cancer-related function

\begin{tabular}{|c|c|c|c|}
\hline Target genes & Type of cancer & Cancer-related function & References \\
\hline \multicolumn{4}{|l|}{ miR-143 } \\
\hline KRAS & $\mathrm{CRC}, \mathrm{PCa}, \mathrm{PaCa}$ & Proliferation & [109] \\
\hline MACC1 & CRC & Metastasis & [110] \\
\hline TLR2 & CRC & Proliferation, invasion & [109] \\
\hline DNMT3A & CRC, BrCa, leukemia & Proliferation & [111-113] \\
\hline Akt & CRC, BC, HCC, glioma & Apoptosis, proliferation & [114-117] \\
\hline ERK5 & CRC, PCa, BC, B-cell malignancy & Proliferation & {$[115,117-119]$} \\
\hline $\mathrm{BCl} 2$ & $\mathrm{CRC}, \mathrm{BrCa}, \mathrm{OC}, \mathrm{BC}$ & Apoptosis & {$[60,92,115,120]$} \\
\hline Survivin & $\mathrm{BrCa}$ & Apoptosis & [89] \\
\hline ARHGEF1 & $\mathrm{PaCa}$ & Metastasis & [92] \\
\hline ARHGEF2 & $\mathrm{PaCa}$ & Proliferation, invasion & [121] \\
\hline FNDC3B & $\mathrm{HCC}$ & Metastasis & [121] \\
\hline Cox2 & $B C, G C$ & Metastasis & {$[117,131]$} \\
\hline MMP-13 & OC, lung & Invasion & {$[122,123]$} \\
\hline Lmk1 & Lung & Metastasis & [124] \\
\hline \multicolumn{4}{|l|}{$\operatorname{miR}-145$} \\
\hline Catenin $\delta-1$ & CRC & Proliferation, invasion & {$[125]$} \\
\hline DFF45 & CRC & Apoptosis & {$[126]$} \\
\hline VEGF & $\mathrm{CRC}, \mathrm{BrCa}, \mathrm{OC}$, thyroid, GB & Angiogenesis & {$[127-130]$} \\
\hline c-Myc & CRC, PCa, EOC, BrCa, PaCa, ESCC, lung, glioma, RCC & Proliferation, invasion, apoptosis & {$[58,131-134]$} \\
\hline PAK4 & CRC & Proliferation, invasion & [135] \\
\hline IRS1 & $\mathrm{CRC}, \mathrm{HCC}, \mathrm{BC}$ & Proliferation & [49] \\
\hline IRS2 & CRC & Proliferation & [84] \\
\hline YES & CRC & Proliferation & [136] \\
\hline STAT1 & CRC & Proliferation & [136] \\
\hline Fascin-1 & CRC, BrCa, BC, ESCC, glioma & Invasion & {$[106,137-140]$} \\
\hline SWAP70 & $\mathrm{PCa}$ & Invasion & [141] \\
\hline ERG & PCa & Proliferation, invasion, apoptosis, angiogenesis & [142] \\
\hline CD44 & PCa, lung & CSC & {$[132,134,143]$} \\
\hline Oct4 & PCa, lung, GCT & CSC & [132] \\
\hline KLF4 & PCa, GCT & CSC & [144] \\
\hline CDK4 & Lung & Proliferation & [145] \\
\hline CDK6 & EOC, OSCC & Proliferation & [146] \\
\hline p70S6K1 & CRC, EOC & Proliferation & [146] \\
\hline Muc-1 & $\mathrm{EOC}, \mathrm{BrCa}$ & Invasion & {$[146,147]$} \\
\hline RTKN & $\mathrm{BrCa}$ & Proliferation, invasion & {$[148,149]$} \\
\hline JAM-A & $\mathrm{BrCa}$ & Proliferation & [150] \\
\hline $\mathrm{ER} \alpha$ & $\mathrm{BrCa}$ & Proliferation & [83] \\
\hline RREB1 & $\mathrm{PaCa}$ & Proliferation, apoptosis & [74] \\
\hline HDAC2 & $\mathrm{HCC}$ & Transcriptional regulation & [103] \\
\hline Ets1 & GC & Migration, apoptosis, angiogenesis & [151] \\
\hline N-cadherin & GC & Invasion & [152] \\
\hline E-cadherin & Thyroid & Invasion & [130] \\
\hline EGFR & Lung, glioma & Proliferation & {$[153,154]$} \\
\hline NUDT1 & $B C$, lung & Proliferation & [153] \\
\hline ROCK1 & OC, glioma & Proliferation, migration & {$[155,156]$} \\
\hline FLT1 & OC & Proliferation & [157] \\
\hline PAK1 & $B C$ & Proliferation, metastasis & [158] \\
\hline $\mathrm{CBF} \beta$ & $\mathrm{BC}$ & Apoptosis & [159] \\
\hline
\end{tabular}


Table 1 continued

\begin{tabular}{|c|c|c|c|}
\hline Target genes & Type of cancer & Cancer-related function & References \\
\hline PPP3CA & $\mathrm{BC}$ & Apoptosis & [159] \\
\hline CLINT1 & $\mathrm{BC}$ & Apoptosis & [159] \\
\hline SOCS7 & $\mathrm{BC}$ & Apoptosis & {$[160]$} \\
\hline Ilk & $\mathrm{BC}$ & Cell division/proliferation & [161] \\
\hline ANGPT2 & $\mathrm{RCC}$ & Angiogenesis & [40] \\
\hline NEDD9 & Glioma, RCC & Proliferation, metastasis & {$[40,98]$} \\
\hline MMP-11 & $\mathrm{RCC}$ & Metastasis & [162] \\
\hline CTGF & Glioma & Proliferation, invasion, metastasis, angiogenesis & [104] \\
\hline ADAM17 & Glioma, RCC, HNSCC & Proliferation, invasion, metastasis, angiogenesis & [96] \\
\hline ADAM22 & Glioma & Metastasis, drug resistance & {$[106]$} \\
\hline Abcg2 & Glioma & Drug resistance, CSC & [51] \\
\hline ADD3 & Glioma & Proliferation, invasion & [70] \\
\hline Sox9 & Glioma, HNSCC & Proliferation, CSC & {$[70,72]$} \\
\hline Sox2 & Glioma, GCT & Proliferation, CSC & {$[97,163]$} \\
\hline Nanog & Glioblastoma & CSC & {$[97]$} \\
\hline PLAUR & Glioblastoma & Metastasis & {$[106]$} \\
\hline SPOCK3 & Glioma & Invasion & {$[106]$} \\
\hline SLC7A5 & Glioma & Proliferation, metastasis & {$[106]$} \\
\hline AKT3 & Thyroid & Metastasis & {$[205]$} \\
\hline \multicolumn{4}{|c|}{ miR-143 and miR-145 } \\
\hline KLF5 & CRC & Proliferation & {$[61]$} \\
\hline Myo6 & PCa & Migration, apoptosis & [164] \\
\hline GOLM1 & PCa & Metastasis & {$[165]$} \\
\hline CD133 & PCa & CSC & [132] \\
\hline IGFIR & $\mathrm{CRC}, \mathrm{HCC}, \mathrm{BC}$ & Proliferation & {$[114,166,167]$} \\
\hline MDM2 & BrCa, HNSCC & Apoptosis & {$[65]$} \\
\hline PAl-1 & $\mathrm{BC}$ & Migration, metastasis & {$[168]$} \\
\hline $\mathrm{HK} 2$ & BrCa, HNSCC, OC, RCC, glioma & Tumor initiation and maintenance & {$[42,86,169-172]$} \\
\hline N-ras & BrCa, glioma & Cell division, proliferation, apoptosis & {$[117,128,173,174]$} \\
\hline ERBB3 & $\mathrm{BrCa}$ & Drug resistance & {$[175]$} \\
\hline
\end{tabular}

CRC colorectal cancer, $P C a$ prostate cancer, PaCa pancreatic cancer, BrCa breast cancer, GC gastric cancer, $H C C$ hepatocellular carcinoma, OC osteosarcoma, $R C C$ renal cell carcinoma, $B C$ bladder cancer, HNSCC head and neck squamous cell carcinoma, GCT germ cell tumor, OSCC oral squamous cell carcinoma, GB gall bladder, EOC epithelial ovarian cancer, ESCC esophageal squamous cell carcinoma

breast cancer cells [63]. The combined introduction of miR-143 and miR-145 in gastric cancer cell line, MKN-1 cells resulted in a higher sensitivity to 5-fluorouracil (5-FU) [64]. Also, inhibition of MDM2 either by miR-143 or miR-145 sensitized HN30 cells to cisplatin, suggesting that this cluster is able to reduce the chemoresistance in HNSCC cells too [65]. Curcumin, a proven chemosensitizing agent in cancer cells, has shown to activate miR-145 expression in HNSCC cells [50] suggesting that the chemosensitizing action of certain agents could be mediated by miRNAs. Also, miR-143 could induce chemosensitivity towards docetaxel in prostate cancer [66] and miR-143-mediated inhibition of Lmk1 enhanced the sensitivity of the NSCLC cells to chemotherapy [67]. Role of miR cluster 143/145 in sensitizing cancer cells to drugs is thus an area of significance in understanding therapeutic interventions in cancer.

\section{Regulation of miR cluster $143 / 145$ in cancers}

The fact that in most of the cancers miR cluster 143/145 was found to be de-regulated points towards the existence of specific mechanisms that regulate their expression in cancer cells. When analyzed at the genetic level, loss of heterogeneity in the miR cluster 143/145 loci was detected in a number of ovarian carcinoma samples [68]. Li et al. found 12 Single nucleotide polymorphisms (SNPs) in the promoter region of miR-143/145 that could attribute to the etiology of colorectal tumors [69]. Increased methylation at $\mathrm{CpG}$ islands on miR-145 promoter could be one reason for the reduced levels which 
is observed in many cancers [70]. Also, HDAC has shown to up-regulate miR cluster 143/145 in Burkitt's lymphoma cells [71]. On the other hand, Peroxisome proliferatoractivated receptor $\gamma$ (PPAR $\gamma$ ) could activate miR-145 by binding to PPAR $\gamma$-responsive element present on the upstream sequence of miR-145 promoter [72].

Evidence suggests that many oncogenic as well as antioncogenic factors mediate their effects through activation or inactivation of miR cluster 143/145 (Table 2). For example, EGFR signals negatively regulate miR cluster $143 / 145$ thereby removing the suppression on many positive regulators of tumorigenesis [73-76]. Ras-responsive element binding factor (RREB1), which is downstream to KRAS-MAPK signaling, was found to down- regulate miR 143/145 cluster expression [75]. Through RREB1, KRAS independently and/or together with members of MAPK and PI3K, has been shown to repress miR $143 / 145$ cluster in pancreatic cancer cells [74]. On the other hand, TGF $\beta$, secreted by cells in scirrhous type of gastric cancer, could activate miR-143 expression in the neighboring stromal fibroblasts thus inducing their proliferation through activation of collagen type III [77]. Upregulation of miR-145 mediated via p65NFkB was also observed in response to Resistin, an adipocyte-derived cytokine, thereby stimulating insulin resistance in HepG2 cells [78]. Similarly, FoxO, a transcription factor which acts down stream to insulin and insulin-like growth factor receptor pathways, suppress $\mathrm{c}-\mathrm{Myc}$ in RCC cells by up-regulating miR-145 along with Mxi1-SR $\alpha$ [79]. BRCA-1, a suppressor of breast cancer, has also proved to be an activator of miR-145 through directly interacting with DROSHA microprocessor complex [80]. Also, some of the antitumor effects shown by p53 are mediated through miR-145 since the abrogation of miR-145 in p53-over-expressed cells reversed the inhibition of p53 on migration, invasion, EMT and stemness of PC3 cells $[81,82]$ and also could be a reason for suppression of cell growth in vitro and in vivo in HNSCC [50] and breast cancer cells [83]. The fact that activation of p53 pathway results in elevation of expression levels of both miR-143 and miR-145 [84, 85] confirms involvement of this cluster in tumor suppression. An interesting observation is that miR-155 has been shown to negatively regulate miR-143 via targeting $\mathrm{C} / \mathrm{EBPb}$, a transcriptional activator of $\mathrm{miR}$ 143 in breast cancer cells [86].

There are various other factors including hormones which have been proved to regulate the expression of miR cluster 143/145 in various cancers. For instance, follicle stimulating hormone (FSH) has been shown to negatively regulate the expression of miR-143 in cervical cells [87]. Cortisol also could reduce miR-145 expression by suppressing $\mathrm{p} 53$ and this may also be mediated by

Table 2 List of molecules that regulate miR cluster 143/145 in cancer

\begin{tabular}{|c|c|c|c|c|}
\hline Regulatory molecules & Cancer type & $\begin{array}{l}\text { Expression of these } \\
\text { regulators in cancer }\end{array}$ & miRNA & References \\
\hline \multicolumn{5}{|l|}{ Positive regulators } \\
\hline FoxO & $\mathrm{RCC}$ & Low & miR-145 & [79] \\
\hline p53 & CRC, BrCa, PCa, HNSCC, Cervical & Low & miR-143, miR-145 & {$[50,83-85]$} \\
\hline TGF- $\beta 1$ & GC & High & miR-143 & [77] \\
\hline BRCA1 & $\mathrm{BrCa}$ & Low & miR-145 & {$[80]$} \\
\hline C/EBP $\beta$ & $\mathrm{BrCa}$ & Low & miR-143 & {$[86]$} \\
\hline PPAR $\gamma$ & CRC & Low & miR-145 & {$[72]$} \\
\hline \multicolumn{5}{|l|}{ Negative regulators } \\
\hline HPV-E6 & HPV-induced cervical & High & miR-145 & [88] \\
\hline RREB1 & CRC & High & miR-143, miR-145 & [74] \\
\hline KRAS & $\mathrm{CRC}, \mathrm{PaCa}$ & High & miR-143, miR-145 & [74] \\
\hline EGFR & CRC & High & miR-143, miR-145 & {$[73-76]$} \\
\hline $\mathrm{ER} \alpha$ & GC & High & miR-143, miR-145 & {$[89,90]$} \\
\hline 17- $\beta$-estradiol & $\mathrm{BrCa}$ & High & miR-143 & {$[92,93]$} \\
\hline Estrogen & $\mathrm{BrCa}$ & High & miR-143, miR-145 & [94] \\
\hline FSH & EOC, cervical & High & miR-143 & {$[176]$} \\
\hline Adam17 & $\mathrm{RCC}$ & High & miR-145 & {$[96]$} \\
\hline Sox2 & Glioma, GCTs & High & miR-143, miR-145 & [97] \\
\hline Limk1 & NSCLC & High & miR-143 & {$[67]$} \\
\hline DDX6 & GC & High & miR-143, miR-145 & [177] \\
\hline
\end{tabular}

CRC colorectal cancer, $P C a$ prostate cancer, $P a C a$ pancreatic cancer, BrCa breast cancer, GC gastric cancer, $R C C$ renal cell carcinoma, $H N S C C$ head and neck squamous cell carcinoma, EOC epithelial ovarian cancer, GCT germ cell tumor, NSCLC non-small cell lung carcinoma 
HPV-E6 expression in HPV-infected cervical cells [88]. It has been reported that ER $\alpha$ inhibits processing of several microRNAs, including miR-145 and miR-143 [89, 90]. ER- $\alpha 36$, whose up-regulation is positively correlated with lymph node metastasis was able to repress miR-143 levels in gastric cancer cells [91]. Likewise 17- $\beta$-estradiol (E2)mediated inhibition of miR-143 could be attributed to the increased proliferation in many cancers [92, 93]. While miR-143 is inhibited by E2, miR-145 has been reported to be regulated by estrogen [94], mediated through the ER binding region within upstream regulatory region of $\mathrm{miR}$ cluster 143/145 [95].

Few targets of miR cluster 143/145 were reported to repress the expression of this cluster, establishing a double negative feedback loop. For example, ADAM17, a proven target of miR-145, could negatively regulate miR145 expression in RCC cells [96]. In gliobloastoma, both miR-143 and miR-145 have been identified as direct targets of Sox 2 whose interaction led to the down-regulation of miR cluster 143/145 which revealed a double negative feedback loop [97]. Another target of miR-145, NEDD9, suppressed miR-145 expression in glioma [98]. Similarly, miR-143 target Limk1 could negatively regulate miR-143 expression in NSCLC cells [67]. Another negative feedback regulation was found in the case of $\mathrm{HPV}^{+\mathrm{ve}}$ cervical cancers. HPV negatively regulated miR-145 in a differentiation-dependent manner [99]. Together, these data suggest that de-regulation of miR cluster 143/145 could add to the incidence as well as progression of cancer.

\section{miR cluster 143/145 and cancer therapy}

miR cluster 143/145 has been demonstrated to be antioncogenic in several cancers, which emphasizes the use of this cluster in a therapeutical approach to treat cancers. As of now, miR cluster 143/145 has been shown to impart their anti-oncogenic effects at various levels including inhibition of proliferation, down-regulation of oncogenes, blocking cell invasion and migration, inducing apoptosis and promoting differentiation. A number of in vivo experiments by various groups have proved the ability of miR cluster $143 / 145$ to intervene oncogenic properties of the cancer cells. Polyethylenimine (PEI)mediated delivery of miR-145, either systemically or locally, to the tumors in mouse xenograft models led to decreased tumor growth, increased apoptosis and inhibition of targets such as c-myc and ERK5 in colon cancer cells [100]. Preliminary experiments with synthetic mimics of these miRNAs suggested that the stable form of such synthetic mimics could be used as therapeutic tool for treating cancers [101, 102]. miRNAs in their original form are easily degradable. To overcome this, chemically modified analogs could be used. As an effort it was found that addition of an aromatic compound type (3'-benzene-pyridine; BP) to the $3^{\prime}$-overhang region of the RNA-strand enhanced the stability of miRNAs. Such stabilized miR-143 (miR-143BP) was able show tumor suppressive effects on CRC cells [102]. In another approach, subcutaneous injection of miR-145 transfected-Hep3B cells into athymic nude mice showed an overall reduction in tumor growth rate and average volume of the tumors [103].

According to a recent report, mesenchymal stem cells (MSCs) could be used as vehicles to deliver miRNAs. In osteosarcoma and gliomas, MSCs were used for effective delivery of miR-145 since MSCs have migrating ability and can easily migrate into the tumors [104]. Introduction of exosome enveloped-miR-143, derived from synthetic miR-143-transfected MSC-conditioned media, significantly reduced the invasion and migration of OC cells and this particular technique can be used for efficient delivery of miRNAs into target cells [105]. Another group that tried retroviral-mediated delivery of miR cluster 143/145 in PaCa cells observed a reduced anchorageindependent growth, though they were unable to find a reduction in the total proliferation rate. Interestingly, miR cluster 143/145 expressing MiaPaCa2 and Panc-1 cells were also unable to form tumors in immune-compromised mice [74]. Adenoviral-mediated ectopic expression of miR-145 using Ad5CMV.Rz.HSVtk.miR145 exerted an enhanced antitumor effect in U87MG/U373MG glioma cells suggesting a possible combination therapy using the hTERT.Rz.HSVtk gene together with miR-145 [106].

Formulation of a proper delivery system is essential for miRNAs to be used in therapies. Pramanik et al. [107] took another step and delivered vectors expressing miR-143/145 conjugated with liposomal nanoparticles in mice. Briefly, nanovectors containing miR143/145 delivered through tail vein of MiaPaCa-2-xenografted mice induced a significant reduction in the tumor size. Upon delivery of miR-143/145, levels of KRAS-2 and RREB1, two known targets of this cluster, were significantly inhibited in the xenografts. Bacteriophage capsid mediated delivery system for miRNAs has also become promising effort in this aspect. miRNAs encapsulated with virus-like particles (VLPs) of bacteriophage MS2 after conjugating with modified HIV-1 Tat47-57 peptide with sulfoSMPB has been reported as an efficient vehicle for delivering miRNAs and could be used to deliver miR cluster 143/145 efficiently to the tumor cells also [108]. Together, these findings are encouraging in the possible therapeutic use of this particular cluster as anti-cancer agents.

\section{Conclusions}

The role of miR cluster 143/145 in cancer is of significance since both miR-143 and miR-145 have been shown 
to suppress tumorigenesis by targeting various genes that play significant roles during the development of cancer. Though these miRNAs have some common targets, they do have specific targets too, thus they act in concert or independently to impart the functions. On the other hand, miR cluster 143/145 is regulated, either positively or negatively, by various factors in cancer cells (Fig. 2). Evidence suggests that many oncogenes repress miR cluster $143 / 145$ in order to impart their oncogenic effects in those cells, whereas anti-oncogenic factors, including transcription factors and drugs, elicit their effects through up-regulation of miR cluster 143/145. The mechanism of their regulation is different is different cell types. Both these miRNAs are supposed to be under the control of a common promoter, and are found to follow a similar pattern of expression in most of the cases. Since miR-145 has a specific upstream regulatory element of $\sim 1.5 \mathrm{~kb}$ length, it could be possible that this miRNA is regulated independent of miR-143. This might be a possible reason for the

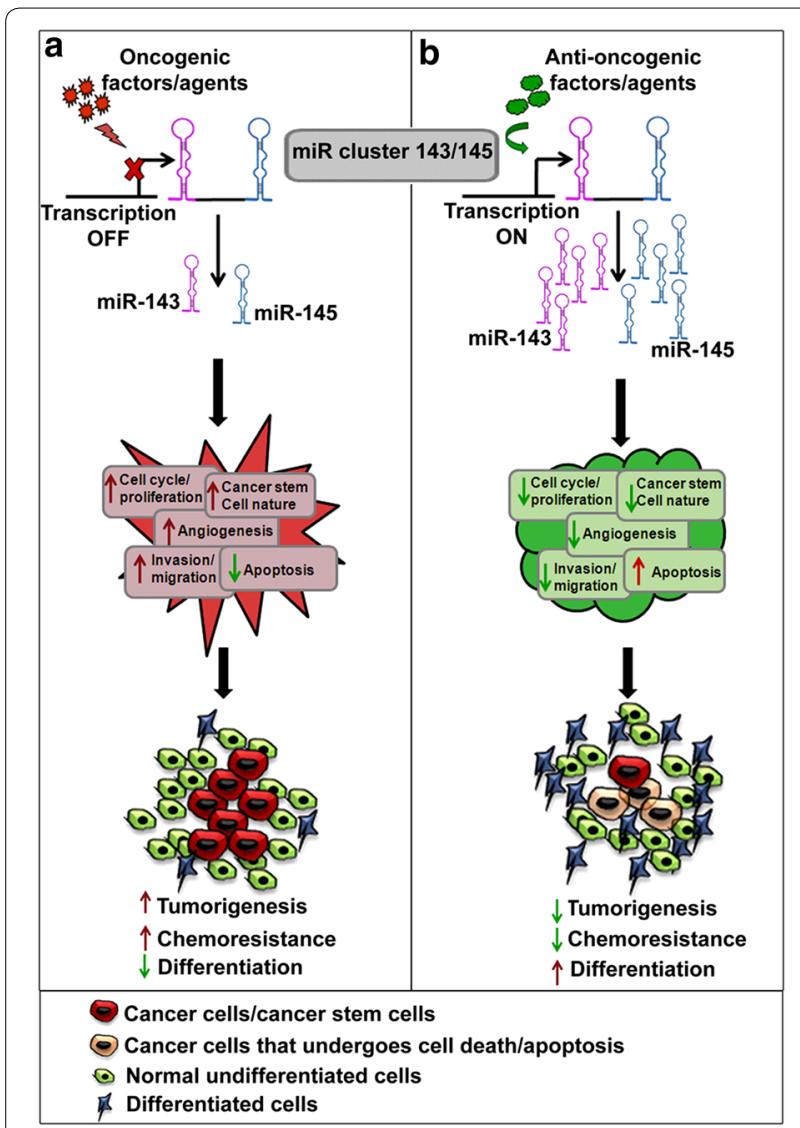

Fig. 2 Schematic representing the involvement of miR cluster $143 / 145$ in tumorigenesis. a Represents that some oncogenic signals can reduce the transcription of miR cluster 143/145 which in turn increase the tumorigenic events resulting in cancer. $\mathbf{b}$ On the other hand, anti-oncogenic signals can up-regulate this cluster which eventually can reduce tumorigenesis disparity in the expression pattern of miR-145 and miR143 in some cell types. However, the reason behind their differential regulation in different cell types is still unclear. More importantly, recent findings suggest that both the miRNAs play an important role in sensitizing cancer cells to various drugs which could be useful for formulating better combination therapy options for cancer. Moreover, expression levels of these miRNAs are most of the time reflected in the serum, suggesting their use as biomarkers for understanding prognosis of the disease. There have been few promising steps taken at the laboratory level to deliver these miRNAs efficiently to tumor sites and have to be investigated further. Taking all these evidences into consideration, miR cluster 143/145 can be regarded as ideal candidates for therapeutic interventions for cancers.

\section{Abbreviations}

DGCR8: DiGeorge syndrome critical region 8; RISC: RNA-induced silencing complex; ABCG2: ATP-binding cassette, subfamily G; MDR1: multidrug resistance protein 1; CDK6: cyclin-dependant kinase 6; Pgp: P-gycoprotein; pRb: retinoblastoma protein; 5-FU: 5-fluorouracil; MDM2: mouse double minute homolog 2; HNSCC: head and neck squamous cell carcinoma; NSCLC: non-small cell lung carcinoma; RCC: renal cell carcinoma; CRC: colorectal cancer; PaCa: pancreatic cancer; HDAC: histone deacetylase; EGFR: epidermal growth factor receptor; KRAS: v-Ki-ras2 Kirsten rat sarcoma viral oncogene homolog; MAPK: mitogen-activated protein kinase; TGF $\beta$ : transforming growth factor beta; PI3K: phosphoinositide-3-kinase; BRCA-1: breast cancer-1, early onset; FoxO: forkhead protein O; EMT: epithelial-to-mesenchymal transition; ER $\alpha$ : estrogen receptor $\alpha$; HPV: human papilloma virus; ADAM17: ADAM metallopeptidase domain 17; Sox2: SRY_box 2; NEDD9: neural precursor cell expressed, developmentally down-regulated 9; Limk1: LIM domain kinase 1; ERK5: extracellular signal-regulated kinase 5.

\section{Authors' contributions}

Both AVD and MRP carried out reading the literature and drafting the manuscript. Both authors read and approved the final manuscript.

\section{Acknowledgements}

The authors thank Dr. Rajesh Raju and Dr. Reshmi G, Computational Biology Group, Cancer Research Program-9, Rajiv Gandhi Centre for Biotechnology for their suggestions and support. We also express our heartfelt apologies to any authors whose work has not been cited in this review due to space constraints.

\section{Compliance with ethical guidelines}

\section{Competing interests}

The authors declare that they have no competing interests.

Received: 15 July 2015 Accepted: 22 September 2015

Published online: 29 September 2015

\section{References}

1. Kim HJ, Chung JK, Hwang do W, Lee DS, Kim S. In vivo imaging of miR-221 biogenesis in papillary thyroid carcinoma. Mol Imaging Biol. 2009;11(2):71-8.

2. Lee Y, Ahn C, Han J, Choi H, Kim J, Yim J, et al. The nuclear RNase III Drosha initiates microRNA processing. Nature. 2003;425(6956):415-9.

3. Denli AM, Tops BB, Plasterk RH, Ketting RF, Hannon GJ. Processing of primary microRNAs by the microprocessor complex. Nature. 2004:432(7014):231-5. 
4. Gregory RI, Yan KP, Amuthan G, Chendrimada T, Doratotaj B, Cooch N, et al. The microprocessor complex mediates the genesis of microRNAs. Nature. 2004;432(7014):235-40.

5. Kim VN. MicroRNA precursors in motion: exportin-5 mediates their nuclear export. Trends Cell Biol. 2004;14(4):156-9.

6. Bartel DP. MicroRNAs: genomics, biogenesis, mechanism, and function. Cell. 2004;116(2):281-97.

7. He L, Hannon GJ. MicroRNAs: small RNAs with a big role in gene regulation. Nat Rev Genet. 2004;5(7):522-31.

8. Lagos-Quintana M, Rauhut R, Meyer J, Borkhardt A, Tuschl T. New microRNAs from mouse and human. RNA. 2003:9(2):175-9.

9. Lagos-Quintana M, Rauhut R, Yalcin A, Meyer J, Lendeckel W, Tuschl T. Identification of tissue-specific microRNAs from mouse. Curr Biol. 2002;12(9):735-9.

10. Miska EA, Alvarez-Saavedra E, Townsend M, Yoshii A, Sestan N, Rakic $P$, et al. Microarray analysis of microRNA expression in the developing mammalian brain. Genome Biol. 2004:5(9):R68.

11. Krek A, Grun D, Poy MN, Wolf R, Rosenberg L, Epstein EJ, et al. Combinatorial microRNA target predictions. Nat Genet. 2005;37(5):495-500

12. Lim LP, Lau NC, Garrett-Engele P, Grimson A, Schelter JM, Castle J, et al. Microarray analysis shows that some microRNAs downregulate large numbers of target mRNAs. Nature. 2005:433(7027):769-73.

13. Xu S. microRNA expression in the eyes and their significance in relation to functions. Prog Retin Eye Res. 2009;28(2):87-116.

14. Wightman B, Ha I, Ruvkun G. Posttranscriptional regulation of the heterochronic gene lin-14 by lin- 4 mediates temporal pattern formation in C. elegans. Cell. 1993;75(5):855-62.

15. Martello G, Zacchigna L, Inui M, Montagner M, Adorno M, Mamidi A, et al. MicroRNA control of Nodal signalling. Nature. 2007:449(7159):183-8.

16. Hipfner DR, Weigmann K, Cohen SM. The bantam gene regulates Drosophila growth. Genetics. 2002;161(4):1527-37.

17. Brennecke J, Cohen SM. Towards a complete description of the microRNA complement of animal genomes. Genome Biol. 2003;4(9):228.

18. Makeyev EV, Zhang J, Carrasco MA, Maniatis T. The MicroRNA miR-124 promotes neuronal differentiation by triggering brain-specific alternative pre-mRNA splicing. Mol Cell. 2007;27(3):435-48.

19. Hatfield SD, Shcherbata HR, Fischer KA, Nakahara K, Carthew RW, Ruohola-Baker $\mathrm{H}$. Stem cell division is regulated by the microRNA pathway. Nature. 2005;435(7044):974-8.

20. Houbaviy HB, Murray MF, Sharp PA. Embryonic stem cell-specific MicroRNAs. Dev Cell. 2003;5(2):351-8.

21. Bernstein E, Kim SY, Carmell MA, Murchison EP, Alcorn H, Li MZ, et al. Dicer is essential for mouse development. Nat Genet. 2003;35(3):215-7.

22. Esquela-Kerscher A, Slack FJ. Oncomirs-microRNAs with a role in cancer. Nat Rev Cancer. 2006;6(4):259-69.

23. Wang $Y$, Lee CG. MicroRNA and cancer-focus on apoptosis. J Cell Mol Med. 2009;13(1):12-23.

24. Calin GA, Dumitru CD, Shimizu M, Bichi R, Zupo S, Noch E, et al. Frequent deletions and down-regulation of micro-RNA genes miR15 and miR16 at 13q14 in chronic lymphocytic leukemia. Proc Natl Acad Sci USA. 2002;99(24):15524-9.

25. He L, Thomson JM, Hemann MT, Hernando-Monge E, Mu D, Goodson S, et al. A microRNA polycistron as a potential human oncogene. Nature. 2005:435(7043):828-33.

26. Johnson SM, Grosshans H, Shingara J, Byrom M, Jarvis R, Cheng A, et al. RAS is regulated by the let-7 microRNA family. Cell. 2005;120(5):635-47.

27. Takamizawa J, Konishi H, Yanagisawa K, Tomida S, Osada H, Endoh H, et al. Reduced expression of the let-7 microRNAs in human lung cancers in association with shortened postoperative survival. Cancer Res. 2004;64(11):3753-6.

28. Iio A, Nakagawa Y, Hirata I, Naoe T, Akao Y. Identification of non-coding RNAs embracing microRNA-143/145 cluster. Mol Cancer. 2010;9:136.

29. Cordes KR, Sheehy NT, White MP, Berry EC, Morton SU, Muth AN, et al. miR-145 and miR-143 regulate smooth muscle cell fate and plasticity. Nature. 2009;460(7256):705-10.

30. Michael MZ, O'Connor SM, van Holst-Pellekaan NG, Young GP, James RJ. Reduced accumulation of specific microRNAs in colorectal neoplasia. Mol Cancer Res. 2003;1(12):882-91.
31. Sempere LF, Christensen M, Silahtaroglu A, Bak M, Heath CV, Schwartz $\mathrm{G}$, et al. Altered MicroRNA expression confined to specific epithelial cell subpopulations in breast cancer. Cancer Res. 2007;67(24):11612-20.

32. Volinia S, Calin GA, Liu CG, Ambs S, Cimmino A, Petrocca F, et al. A microRNA expression signature of human solid tumors defines cancer gene targets. Proc Natl Acad Sci USA. 2006;103(7):2257-61.

33. Dyrskjot L, Ostenfeld MS, Bramsen JB, Silahtaroglu AN, Lamy P, Ramanathan $\mathrm{R}$, et al. Genomic profiling of microRNAs in bladder cancer: miR129 is associated with poor outcome and promotes cell death in vitro. Cancer Res. 2009;69(11):4851-60.

34. Amaral FC, Torres N, Saggioro F, Neder L, Machado HR, Silva WA Jr, et al. MicroRNAs differentially expressed in ACTH-secreting pituitary tumors. J Clin Endocrinol Metab. 2009;94(1):320-3.

35. Gillis AJ, Stoop HJ, Hersmus R, Oosterhuis JW, Sun Y, Chen C, et al. High-throughput microRNAome analysis in human germ cell tumours. J Pathol. 2007;213(3):319-28.

36. Misra S, Chaturvedi A, Misra NC, Sharma ID. Carcinoma of the gallbladder. Lancet Oncol. 2003;4(3):167-76.

37. Miller G, Jarnagin WR. Gallbladder carcinoma. Eur J Surg Oncol. 2008;34(3):306-12.

38. Slaby O, Redova M, Poprach A, Nekvindova J, Iliev R, Radova L, et al. Identification of MicroRNAs associated with early relapse after nephrectomy in renal cell carcinoma patients. Genes Chromosomes Cancer. 2012;51(7):707-16.

39. Wach S, Nolte E, Theil A, Stohr C, Rau TT, Hartmann A, et al. MicroRNA profiles classify papillary renal cell carcinoma subtypes. Br J Cancer. 2013;109(3):714-22

40. Lu R, Ji Z, Li X, Zhai Q, Zhao C, Jiang Z, et al. miR-145 functions as tumor suppressor and targets two oncogenes, ANGPT2 and NEDD9, in renal cell carcinoma. J Cancer Res Clin Oncol. 2014;140(3):387-97.

41. Hu H, Zhang Y, Cai XH, Huang JF, Cai L. Changes in microRNA expression in the MG-63 osteosarcoma cell line compared with osteoblasts. Oncol Lett. 2012;4(5):1037-42.

42. Zhang H, Cai X, Wang Y, Tang H, Tong D, Ji F. microRNA-143, down-regulated in osteosarcoma, promotes apoptosis and suppresses tumorigenicity by targeting Bcl-2. Oncol Rep. 2010;24(5):1363-9.

43. Yamagata T, Yoshizawa J, Ohashi S, Yanaga K, Ohki T. Expression patterns of microRNAs are altered in hypoxic human neuroblastoma cells Pediatr Surg Int. 2010;26(12):1179-84.

44. Zhang H, Pu J, Qi T, Qi M, Yang C, Li S, et al. MicroRNA-145 inhibits the growth, invasion, metastasis and angiogenesis of neuroblastoma cells through targeting hypoxia-inducible factor 2 alpha. Oncogene. 2014;33(3):387-97.

45. Avgeris M, Stravodimos K, Fragoulis EG, Scorilas A. The loss of the tumour-suppressor miR-145 results in the shorter disease-free survival of prostate cancer patients. Br J Cancer. 2013;108(12):2573-81.

46. Huang L, Lin JX, Yu YH, Zhang MY, Wang HY, Zheng M. Downregulation of six microRNAs is associated with advanced stage, lymph node metastasis and poor prognosis in small cell carcinoma of the cervix. PLoS One. 2012;7(3):e33762.

47. Varnholt H, Drebber U, Schulze F, Wedemeyer I, Schirmacher P, Dienes $\mathrm{HP}$, et al. MicroRNA gene expression profile of hepatitis $C$ virus-associated hepatocellular carcinoma. Hepatology. 2008;47(4):1223-32.

48. Karakatsanis A, Papaconstantinou I, Gazouli M, Lyberopoulou A, Polymeneas G, Voros D. Expression of microRNAs, miR-21, miR-31, miR-122, miR-145, miR-146a, miR-200c, miR-221, miR-222, and miR-223 in patients with hepatocellular carcinoma or intrahepatic cholangiocarcinoma and its prognostic significance. Mol Carcinog 2011;52(4):297-303.

49. Law PT, Ching AK, Chan AW, Wong QW, Wong CK, To KF, et al. MiR-145 modulates multiple components of the insulin-like growth factor pathway in hepatocellular carcinoma. Carcinogenesis. 2012;33(6):1134-41.

50. Yu CC, Tsai LL, Wang ML, Yu CH, Lo WL, Chang YC, et al. miR145 targets the SOX9/ADAM17 axis to inhibit tumor-initiating cells and IL-6-mediated paracrine effects in head and neck cancer. Cancer Res. 2013;73(11):3425-40.

51. Shi L, Wang Z, Sun G, Wan Y, Guo J, Fu X. miR-145 inhibits migration and invasion of glioma stem cells by targeting ABCG2. Neuromolecular Med. 2014;16(2):517-28. 
52. Andersen M, Grauslund M, Ravn J, Sorensen JB, Andersen CB, Santoni-Rugiu E. Diagnostic potential of miR-126, miR-143, miR145, and miR-652 in malignant pleural mesothelioma. J Mol Diagn. 2014;16(4):418-30.

53. Cioce M, Ganci F, Canu V, Sacconi A, Mori F, Canino C, et al. Protumorigenic effects of mir-145 loss in malignant pleural mesothelioma. Oncogene. 2013;33(46):5319-31.

54. Izzotti A, Calin GA, Arrigo P, Steele VE, Croce CM, De Flora S. Downregulation of microRNA expression in the lungs of rats exposed to cigarette smoke. Faseb J. 2009;23(3):806-12.

55. Ikemura K, Yamamoto M, Miyazaki S, Mizutani H, Iwamoto T, Okuda M. MicroRNA-145 post-transcriptionally regulates the expression and function of P-glycoprotein in intestinal epithelial cells. Mol Pharmacol. 2013:83(2):399-405.

56. Lee SK, Teng Y, Wong HK, Ng TK, Huang L, Lei P, et al. MicroRNA-145 regulates human corneal epithelial differentiation. PLOS ONE. 2011;6(6):e21249.

57. Zhu L, Liu J, Liang F, Rayner S, Xiong J. Predicting response to preoperative chemotherapy agents by identifying drug action on modeled microRNA regulation networks. PLoS ONE. 2014;9(5):e98140.

58. Zhu X, Li Y, Xie C, Yin X, Liu Y, Cao Y, et al. miR-145 sensitizes ovarian cancer cells to paclitaxel by targeting Sp1 and Cdk6. Int J Cancer. 2014;135(6):1286-96.

59. Peng W, Hu J, Zhu XD, Liu X, Wang CC, Li WH, et al. Overexpression of miR-145 increases the sensitivity of vemurafenib in drug-resistant colo205 cell line. Tumour Biol. 2014;35(4):2983-8.

60. Borralho PM, Kren BT, Castro RE, da Silva IB, Steer CJ, Rodrigues CM. MicroRNA-143 reduces viability and increases sensitivity to 5-fluorouracil in HCT116 human colorectal cancer cells. FEBS J. 2009;276(22):6689-700.

61. Pagliuca A, Valvo C, Fabrizi E, di Martino S, Biffoni M, Runci D, et al. Analysis of the combined action of miR-143 and miR-145 on oncogenic pathways in colorectal cancer cells reveals a coordinate program of gene repression. Oncogene. 2013;32(40):4806-13.

62. Yang YP, Chien Y, Chiou GY, Cherng JY, Wang ML, Lo WL, et al. Inhibition of cancer stem cell-like properties and reduced chemoradioresistance of glioblastoma using microRNA145 with cationic polyurethane-short branch PEl. Biomaterials. 2012;33(5):1462-76.

63. Kim SJ, Oh JS, Shin JY, Lee KD, Sung KW, Nam SJ, et al. Development of microRNA-145 for therapeutic application in breast cancer. J Control Release. 2011;155(3):427-34.

64. Takagi T, lio A, Nakagawa Y, Naoe T, Tanigawa N, Akao Y. Decreased expression of microRNA-143 and -145 in human gastric cancers. Oncology. 2009;77(1):12-21.

65. Zhang J, Sun Q, Zhang Z, Ge S, Han ZG, Chen WT. Loss of microRNA-143/145 disturbs cellular growth and apoptosis of human epithelial cancers by impairing the MDM2-p53 feedback loop. Oncogene. 2013;32(1):61-9.

66. Xu B, Niu X, Zhang X, Tao J, Wu D, Wang Z, et al. miR-143 decreases prostate cancer cells proliferation and migration and enhances their sensitivity to docetaxel through suppression of KRAS. Mol Cell Biochem. 2011;350(1-2):207-13.

67. Xia H, Sun S, Wang B, Wang T, Liang C, Li G, et al. miR-143 inhibits NSCLC cell growth and metastasis by targeting Limk1. Int J Mol Sci. 2014;15(7):11973-83.

68. Bearfoot JL, Choong DY, Gorringe KL, Campbell IG. Genetic analysis of cancer-implicated MicroRNA in ovarian cancer. Clin Cancer Res. 2008;14(22):7246-50.

69. Li L, Pan X, Li Z, Bai P, Jin H, Wang T, et al. Association between polymorphisms in the promoter region of miR-143/145 and risk of colorectal cancer. Hum Immunol. 2013;74(8):993-7.

70. Rani SB, Rathod SS, Karthik S, Kaur N, Muzumdar D, Shiras AS. MiR-145 functions as a tumor-suppressive RNA by targeting Sox9 and adducin 3 in human glioma cells. Neuro Oncol. 2013;15(10):1302-16.

71. Ferreira AC, Robaina MC, Rezende LM, Severino P, Klumb CE. Histone deacetylase inhibitor prevents cell growth in Burkitt's lymphoma by regulating PI3K/Akt pathways and leads to upregulation of miR-143, miR-145, and miR-101. Ann Hematol. 2014;93(6):983-93.

72. Panza A, Votino C, Gentile A, Valvano MR, Colangelo T, Pancione M, et al. Peroxisome proliferator-activated receptor gamma-mediated induction of microRNA-145 opposes tumor phenotype in colorectal cancer. Biochim Biophys Acta. 2014;1843(6):1225-36.

73. Zhu H, Dougherty U, Robinson V, Mustafi R, Pekow J, Kupfer S, et al. EGFR signals downregulate tumor suppressors miR-143 and miR-145 in Western diet-promoted murine colon cancer: role of $\mathrm{G} 1$ regulators. Mol Cancer Res. 2011;9(7):960-75.

74. Kent OA, Chivukula RR, Mullendore M, Wentzel EA, Feldmann G, Lee $\mathrm{KH}$, et al. Repression of the miR-143/145 cluster by oncogenic Ras initiates a tumor-promoting feed-forward pathway. Genes Dev. 2010;24(24):2754-9.

75. Kent OA, Fox-Talbot K, Halushka MK. RREB1 repressed miR-143/145 modulates KRAS signaling through downregulation of multiple targets. Oncogene. 2013;32(20):2576-85.

76. Kent OA, McCall MN, Cornish TC, Halushka MK. Lessons from miR143/145: the importance of cell-type localization of miRNAs. Nucleic Acids Res. 2014;42(12):7528-38.

77. Naito Y, Yasuno K, Tagawa H, Sakamoto N, Oue N, Yashiro M, et al. MicroRNA-145 is a potential prognostic factor of scirrhous type gastric cancer. Oncol Rep. 2014;32(4):1720-6.

78. Wen F, Yang Y, Jin D, Sun J, Yu X, Yang Z. MiRNA-145 is involved in the development of resistin-induced insulin resistance in HepG2 cells. Biochem Biophys Res Commun. 2014;445(2):517-23.

79. Gan B, Lim C, Chu G, Hua S, Ding Z, Collins M, et al. FoxOs enforce a progression checkpoint to constrain mTORC1-activated renal tumorigenesis. Cancer Cell. 2010;18(5):472-84.

80. Kawai $\mathrm{S}, \mathrm{Amano} A$. BRCA1 regulates microRNA biogenesis via the DROSHA microprocessor complex. J Cell Biol. 2012;197(2):201-8.

81. Ren D, Wang M, Guo W, Zhao X, Tu X, Huang S, et al. Wild-type p53 suppresses the epithelial-mesenchymal transition and stemness in PC-3 prostate cancer cells by modulating miR145. Int J Oncol. 2013:42(4):1473-81.

82. Suh SO, Chen Y, Zaman MS, Hirata H, Yamamura S, Shahryari V, et al. MicroRNA-145 is regulated by DNA methylation and p53 gene mutation in prostate cancer. Carcinogenesis. 2011;32(5):772-8.

83. Spizzo R, Nicoloso MS, Lupini L, Lu Y, Fogarty J, Rossi S, et al. miR-145 participates with TP53 in a death-promoting regulatory loop and targets estrogen receptor-alpha in human breast cancer cells. Cell Death Differ. 2010;17(2):246-54.

84. Sachdeva M, Zhu S, Wu F, Wu H, Walia V, Kumar S, et al. p53 represses c-Myc through induction of the tumor suppressor miR-145. Proc Natl Acad Sci USA. 2009;106(9):3207-12.

85. Suzuki HI, Yamagata K, Sugimoto K, Iwamoto T, Kato S, Miyazono K. Modulation of microRNA processing by p53. Nature. 2009:460(7254):529-33.

86. Jiang S, Zhang LF, Zhang HW, Hu S, Lu MH, Liang S, et al. A novel miR155/miR-143 cascade controls glycolysis by regulating hexokinase 2 in breast cancer cells. EMBO J. 2012;31(8):1985-98.

87. Yao N, Yang BQ, Liu Y, Tan XY, Lu CL, Yuan XH, et al. Follicle-stimulating hormone regulation of microRNA expression on progesterone production in cultured rat granulosa cells. Endocrine. 2010;38(2):158-66.

88. Shi M, Du L, Liu D, Qian L, Hu M, Yu M, et al. Glucocorticoid regulation of a novel HPV-E6-p53-miR-145 pathway modulates invasion and therapy resistance of cervical cancer cells. J Pathol. 2012;228(2):148-57.

89. Boominathan L. Curcumin functions as a positive regulator of miRNA processing and a negative regulator of cancer stem cell proliferation. Nat Proc. 2009;. doi:10.1038/npre.2009.4110.1.

90. Deng D, Liu Z, Du Y. Epigenetic alterations as cancer diagnostic, prognostic, and predictive biomarkers. Adv Genet. 2010;71:125-76.

91. Feng Z, Shangkun Z, Yan L, Ying C, Lijiang L. miR-143 is associated with ER-a36 expression in gastric carcinoma of xenografted model. J Biomim Biomater Tissue Eng. 2013;18:117.

92. Yu X, Zhang X, Dhakal IB, Beggs M, Kadlubar S, Luo D. Induction of cell proliferation and survival genes by estradiol-repressed microRNAs in breast cancer cells. BMC Cancer. 2012;12:29.

93. Bhat-Nakshatri P, Wang G, Collins NR, Thomson MJ, Geistlinger TR, Carroll JS, et al. Estradiol-regulated microRNAs control estradiol response in breast cancer cells. Nucleic Acids Res. 2009;37(14):4850-61.

94. Dai R, Phillips RA, Zhang Y, Khan D, Crasta O, Ahmed SA. Suppression of LPS-induced Interferon-gamma and nitric oxide in splenic lymphocytes by select estrogen-regulated microRNAs: a novel mechanism of immune modulation. Blood. 2008;112(12):4591-7. 
95. Xu J, Zhou X, Wong C. Genome-wide identification of estrogen receptor alpha regulated miRNAs using transcription factor binding data. In: Mahdavi DMA, editor. Bioinformatics-Trends and methodologies. Croatia: In Tech; 2011. p. 559-74.

96. Doberstein K, Steinmeyer N, Hartmetz AK, Eberhardt W, Mittelbronn M, Harter PN, et al. MicroRNA-145 targets the metalloprotease ADAM17 and is suppressed in renal cell carcinoma patients. Neoplasia. 2013;15(2):218-30.

97. Fang $X$, Yoon JG, Li L, Yu W, Shao J, Hua D, et al. The SOX2 response program in glioblastoma multiforme: an integrated ChIP-seq, expression microarray, and microRNA analysis. BMC Genom. 2011;12:11.

98. Speranza MC, Frattini V, Pisati F, Kapetis D, Porrati P, Eoli M, et al. NEDD9, a novel target of miR-145, increases the invasiveness of glioblastoma. Oncotarget. 2012;3(7):723-34.

99. Gunasekharan V, Laimins LA. Human papillomaviruses modulate microRNA 145 expression to directly control genome amplification. J Virol. 2013;87(10):6037-43.

100. Ibrahim AF, Weirauch U, Thomas M, Grunweller A, Hartmann RK, Aigner A. MicroRNA replacement therapy for miR-145 and miR-33a is efficacious in a model of colon carcinoma. Cancer Res. 2011;71(15):5214-24.

101. Akao Y, Nakagawa Y, Hirata I, lio A, Itoh T, Kojima K, et al. Role of antioncomirs miR-143 and -145 in human colorectal tumors. Cancer Gene Ther. 2010;17(6):398-408.

102. Kitade Y, Akao Y. MicroRNAs and their therapeutic potential for human diseases: microRNAs, miR-143 and -145, function as anti-oncomirs and the application of chemically modified miR-143 as an anti-cancer drug. J Pharmacol Sci. 2010;114(3):276-80.

103. Noh JH, Chang YG, Kim MG, Jung KH, Kim JK, Bae HJ, et al. MiR-145 functions as a tumor suppressor by directly targeting histone deacetylase 2 in liver cancer. Cancer Lett. 2013;335(2):455-62.

104. Lee HK, Bier A, Cazacu S, Finniss S, Xiang C, Twito H, et al. MicroRNA-145 is downregulated in glial tumors and regulates glioma cell migration by targeting connective tissue growth factor. PLoS One. 2013;8(2):e54652.

105. Shimbo K, Miyaki S, Ishitobi H, Kato Y, Kubo T, Shimose S, et al. Exosomeformed synthetic microRNA-143 is transferred to osteosarcoma cells and inhibits their migration. Biochem Biophys Res Commun. 2014;445(2):381-7.

106. Lee SJ, Kim SJ, Seo HH, Shin SP, Kim D, Park CS, et al. Over-expression of miR-145 enhances the effectiveness of HSVtk gene therapy for malignant glioma. Cancer Lett. 2012;320(1):72-80.

107. Pramanik D, Campbell NR, Karikari C, Chivukula R, Kent OA, Mendell JT, et al. Restitution of tumor suppressor microRNAs using a systemic nanovector inhibits pancreatic cancer growth in mice. Mol Cancer Ther. 2011;10(8):1470-80.

108. Pan Y, Zhang Y, Jia T, Zhang K, Li J, Wang L. Development of a microRNA delivery system based on bacteriophage MS2 virus-like particles. FEBS J. 2012;279(7):1198-208.

109. Guo H, Chen Y, Hu X, Qian G, Ge S, Zhang J. The regulation of Toll-like receptor 2 by miR-143 suppresses the invasion and migration of a subset of human colorectal carcinoma cells. Mol Cancer. 2013;12:77.

110. Zhang Y, Wang Z, Chen M, Peng L, Wang X, Ma Q, et al. MicroRNA-143 targets MACC 1 to inhibit cell invasion and migration in colorectal cancer. Mol Cancer. 2012;11:23.

111. Ng EK, Tsang WP, Ng SS, Jin HC, Yu J, Li JJ, et al. MicroRNA-143 targets DNA methyltransferases $3 \mathrm{~A}$ in colorectal cancer. Br J Cancer. 2009;101(4):699-706.

112. Ng EK, Li R, Shin VY, Siu JM, Ma ES, Kwong A. MicroRNA-143 is downregulated in breast cancer and regulates DNA methyltransferases $3 \mathrm{~A}$ in breast cancer cells. Tumour Biol. 2014;35(3):2591-8.

113. Shen JZ, Zhang YY, Fu HY, Wu DS, Zhou HR. Overexpression of microRNA-143 inhibits growth and induces apoptosis in human leukemia cells. Oncol Rep. 2014;31(5):2035-42.

114. Qian X, Yu J, Yin Y, He J, Wang L, Li Q, et al. MicroRNA-143 inhibits tumor growth and angiogenesis and sensitizes chemosensitivity to oxaliplatin in colorectal cancers. Cell Cycle. 2013;12(9):1385-94.

115. Noguchi S, Mori T, Hoshino Y, Maruo K, Yamada N, Kitade Y, et al. MicroRNA-143 functions as a tumor suppressor in human bladder cancer T24 cells. Cancer Lett. 2011;307(2):211-20.

116. Wang Y, Hu C, Cheng J, Chen B, Ke Q, Lv Z, et al. MicroRNA-145 suppresses hepatocellular carcinoma by targeting IRS1 and its downstream Akt signaling. Biochem Biophys Res Commun. 2014;446(4):1255-60.
117. Wang L, Shi ZM, Jiang CF, Liu X, Chen QD, Qian X, et al. MiR-143 acts as a tumor suppressor by targeting N-RAS and enhances temozolomideinduced apoptosis in glioma. Oncotarget. 2014;5(14):5416-27.

118. Ahmad I, Singh LB, Yang ZH, Kalna G, Fleming J, Fisher G, et al. Mir143 expression inversely correlates with nuclear ERK5 immunoreactivity in clinical prostate cancer. Br J Cancer. 2013;108(1):149-54.

119. Ni Y, Meng L, Wang L, Dong W, Shen H, Wang G, et al. MicroRNA-143 functions as a tumor suppressor in human esophageal squamous cell carcinoma. Gene. 2013;517(2):197-204.

120. Liu L, Yu X, Guo X, Tian Z, Su M, Long Y, et al. miR-143 is downregulated in cervical cancer and promotes apoptosis and inhibits tumor formation by targeting Bcl-2. Mol Med Rep. 2012;5(3):753-60.

121. Hu Y, Ou Y, Wu K, Chen Y, Sun W. miR-143 inhibits the metastasis of pancreatic cancer and an associated signaling pathway. Tumour Biol. 2012;33(6):1863-70.

122. Wu XL, Cheng B, Li PY, Huang HJ, Zhao Q, Dan ZL, et al. MicroRNA-143 suppresses gastric cancer cell growth and induces apoptosis by targeting COX-2. World J Gastroenterol. 2013;19(43):7758-65.

123. Song T, Zhang X, Wang C, Wu Y, Dong J, Gao J, et al. Expression of miR-143 reduces growth and migration of human bladder carcinoma cells by targeting cyclooxygenase-2. Asian Pac J Cancer Prev. 2011;12(4):929-33.

124. Osaki M, Takeshita F, Sugimoto Y, Kosaka N, Yamamoto Y, Yoshioka $Y$, et al. MicroRNA-143 regulates human osteosarcoma metastasis by regulating matrix metalloprotease-13 expression. Mol Ther. 2011;19(6):1123-30.

125. Yamada N, Noguchi S, Mori T, Naoe T, Maruo K, Akao Y. Tumorsuppressive microRNA-145 targets catenin delta-1 to regulate Wnt/ beta-catenin signaling in human colon cancer cells. Cancer Lett. 2013;335(2):332-42.

126. Zhang J, Guo H, Qian G, Ge S, Ji H, Hu X, et al. MiR-145, a new regulator of the DNA fragmentation factor-45 (DFF45)-mediated apoptotic network. Mol Cancer. 2010;9:211.

127. Xu Q, Liu LZ, Qian X, Chen Q, Jiang Y, Li D, et al. MiR-145 directly targets p70S6K1 in cancer cells to inhibit tumor growth and angiogenesis. Nucleic Acids Res. 2012;40(2):761-74

128. Zou C, Xu Q, Mao F, Li D, Bian C, Liu LZ, et al. MiR-145 inhibits tumor angiogenesis and growth by N-RAS and VEGF. Cell Cycle. 2012;11(11):2137-45.

129. Fan $L$, Wu Q, Xing X, Wei Y, Shao Z. MicroRNA-145 targets vascular endothelial growth factor and inhibits invasion and metastasis of osteosarcoma cells. Acta Biochim Biophys Sin (Shanghai). 2012;44(5):407-14.

130. Boufragech $M$, Zhang $L$, Jain M, Patel D, Ellis $R$, Xiong $Y$, et al. miR-145 suppresses thyroid cancer growth and metastasis and targets AKT3. Endocr Relat Cancer. 2014;21(4):517-31.

131. Shi B, Sepp-Lorenzino L, Prisco M, Linsley P, deAngelis T, Baserga R. Micro RNA 145 targets the insulin receptor substrate-1 and inhibits the growth of colon cancer cells. J Biol Chem. 2007;282(45):32582-90.

132. Huang S, Guo W, Tang Y, Ren D, Zou X, Peng X. miR-143 and miR-145 inhibit stem cell characteristics of PC-3 prostate cancer cells. Oncol Rep. 2012;28(5):1831-7.

133. Wang F, Xia J, Wang N, Zong H. miR-145 inhibits proliferation and invasion of esophageal squamous cell carcinoma in part by targeting c-Myc. Onkologie. 2013;36(12):754-8.

134. Yin R, Zhang S, Wu Y, Fan X, Jiang F, Zhang Z, et al. microRNA-145 suppresses lung adenocarcinoma-initiating cell proliferation by targeting OCT4. Oncol Rep. 2011;25(6):1747-54.

135. Wang Z, Zhang X, Yang Z, Du H, Wu Z, Gong J, et al. MiR-145 regulates PAK4 via the MAPK pathway and exhibits an antitumor effect in human colon cells. Biochem Biophys Res Commun. 2012;427(3):444-9.

136. Gregersen $L H$, Jacobsen $A B$, Frankel LB, Wen J, Krogh A, Lund AH. MicroRNA-145 targets YES and STAT1 in colon cancer cells. PLOS ONE. 2010;5(1):e8836.

137. Feng Y, Zhu J, Ou C, Deng Z, Chen M, Huang W, et al. MicroRNA-145 inhibits tumour growth and metastasis in colorectal cancer by targeting fascin-1. Br J Cancer. 2014;110(9):2300-9.

138. Liu R, Liao J, Yang M, Sheng J, Yang H, Wang Y, et al. The cluster of miR-143 and miR-145 affects the risk for esophageal squamous cell carcinoma through co-regulating fascin homolog 1. PLOS ONE. 2012;7(3):e33987. 
139. Kano M, Seki N, Kikkawa N, Fujimura L, Hoshino I, Akutsu Y, et al. miR-145, miR-133a and miR-133b: Tumor-suppressive miRNAs target FSCN1 in esophageal squamous cell carcinoma. Int J Cancer. 2010;127(12):2804-14.

140. Chiyomaru T, Enokida H, Tatarano S, Kawahara K, Uchida Y, Nishiyama K, et al. miR-145 and miR-133a function as tumour suppressors and directly regulate FSCN1 expression in bladder cancer. Br J Cancer. 2010;102(5):883-91.

141. Chiyomaru T, Tatarano S, Kawakami K, Enokida H, Yoshino H, Nohata $\mathrm{N}$, et al. SWAP70, actin-binding protein, function as an oncogene targeting tumor-suppressive miR-145 in prostate cancer. Prostate. 2011;71(14):1559-67.

142. Hart M, Wach S, Nolte E, Szczyrba J, Menon R, Taubert H, et al. The proto-oncogene ERG is a target of microRNA miR-145 in prostate cancer. FEBS J. 2013;280(9):2105-16.

143. Xu N, Papagiannakopoulos T, Pan G, Thomson JA, Kosik KS. MicroRNA-145 regulates OCT4, SOX2, and KLF4 and represses pluripotency in human embryonic stem cells. Cell. 2009;137(4):647-58.

144. Chen Z, Zeng H, Guo Y, Liu P, Pan H, Deng A, et al. miRNA-145 inhibits non-small cell lung cancer cell proliferation by targeting c-Myc. J Exp Clin Cancer Res. 2010;29:151

145. Wang X, Tang S, Le SY, Lu R, Rader JS, Meyers C, et al. Aberrant expression of oncogenic and tumor-suppressive microRNAs in cervical cancer is required for cancer cell growth. PLoS One. 2008;3(7):e2557.

146. Wu H, Xiao Z, Wang K, Liu W, Hao Q. MiR-145 is downregulated in human ovarian cancer and modulates cell growth and invasion by targeting p70S6K1 and MUC1. Biochem Biophys Res Commun. 2013;441(4):693-700.

147. Sachdeva M, Mo YY. MicroRNA-145 suppresses cell invasion and metastasis by directly targeting mucin 1. Cancer Res. 2010;70(1):378-87.

148. Polytarchou C, lliopoulos D, Struhl K. An integrated transcriptional regulatory circuit that reinforces the breast cancer stem cell state. Proc Natl Acad Sci USA. 2012;109(36):14470-5.

149. Wang S, Bian C, Yang Z, Bo Y, Li J, Zeng L, et al. miR-145 inhibits breast cancer cell growth through RTKN. Int J Oncol. 2009;34(5):1461-6.

150. Gotte M, Mohr C, Koo CY, Stock C, Vaske AK, Viola M, et al. miR-145-dependent targeting of junctional adhesion molecule $A$ and modulation of fascin expression are associated with reduced breast cancer cell motility and invasiveness. Oncogene. 2010;29(50):6569-80.

151. Furlan A, Vercamer C, Desbiens X, Pourtier A. Ets-1 triggers and orchestrates the malignant phenotype of mammary cancer cells within their matrix environment. J Cell Physiol. 2008;215(3):782-93.

152. Gao P, Xing AY, Zhou GY, Zhang TG, Zhang JP, Gao C, et al. The molecular mechanism of microRNA-145 to suppress invasion-metastasis cascade in gastric cancer. Oncogene. 2013;32(4):491-501.

153. Cho WC, Chow AS, Au JS. Restoration of tumour suppressor hsamiR-145 inhibits cancer cell growth in lung adenocarcinoma patients with epidermal growth factor receptor mutation. Eur J Cancer. 2009;45(12):2197-206

154. Lu Y, Chopp M, Zheng X, Katakowski M, Buller B, Jiang F. MiR-145 reduces ADAM17 expression and inhibits in vitro migration and invasion of glioma cells. Oncol Rep. 2013;29(1):67-72.

155. Li E, Zhang J, Yuan T, Ma B. MiR-145 inhibits osteosarcoma cells proliferation and invasion by targeting ROCK1. Tumour Biol. 2014;35(8):7645-50.

156. Wan X, Cheng Q, Peng R, Ma Z, Chen Z, Cao Y, et al. ROCK1, a novel target of miR-145, promotes glioma cell invasion. Mol Med Rep. 2014;9(5):1877-82

157. Ban J, Jug G, Mestdagh P, Schwentner R, Kauer M, Aryee DN, et al. Hsamir-145 is the top EWS-FLI1-repressed microRNA involved in a positive feedback loop in Ewing's sarcoma. Oncogene. 2011;30(18):2173-80.

158. Kou B, Gao Y, Du C, Shi Q, Xu S, Wang CQ, et al. miR-145 inhibits invasion of bladder cancer cells by targeting PAK1. Urol Oncol. 2014:32(6):846-54.
159. Ostenfeld MS, Bramsen JB, Lamy P, Villadsen SB, Fristrup N, Sorensen KD, et al. miR-145 induces caspase-dependent and -independent cell death in urothelial cancer cell lines with targeting of an expression signature present in Ta bladder tumors. Oncogene. 2010;29(7):1073-84.

160. Noguchi S, Yamada N, Kumazaki M, Yasui Y, Iwasaki J, Naito S, et al. socs7, a target gene of microRNA-145, regulates interferon-beta induction through STAT3 nuclear translocation in bladder cancer cells. Cell Death Dis. 2013;4:e482.

161. Noguchi S, Yasui Y, Iwasaki J, Kumazaki M, Yamada N, Naito S, et al. Replacement treatment with microRNA-143 and -145 induces synergistic inhibition of the growth of human bladder cancer cells by regulating PI3K/Akt and MAPK signaling pathways. Cancer Lett. 2013;328(2):353-61.

162. Wu D, Li M, Wang L, Zhou Y, Zhou J, Pan H, et al. microRNA-145 inhibits cell proliferation, migration and invasion by targeting matrix metallopeptidase-11 in renal cell carcinoma. Mol Med Rep. 2014;10(1):393-8.

163. Xu F, Wang H, Zhang X, Liu T, Liu Z. Cell proliferation and invasion ability of human choriocarcinoma cells lessened due to inhibition of Sox 2 expression by microRNA-145. Exp Ther Med. 2013;5(1):77-84.

164. Szczyrba J, Loprich E, Wach S, Jung V, Unteregger G, Barth S, et al. The microRNA profile of prostate carcinoma obtained by deep sequencing. Mol Cancer Res. 2010;8(4):529-38.

165. Kojima S, Enokida H, Yoshino H, Itesako T, Chiyomaru T, Kinoshita T, et al. The tumor-suppressive microRNA-143/145 cluster inhibits cell migration and invasion by targeting GOLM1 in prostate cancer. J Hum Genet. 2014;59(2):78-87.

166. La Rocca G, Badin M, Shi B, Xu SQ, Deangelis T, Sepp-Lorenzinoi L, et al. Mechanism of growth inhibition by MicroRNA 145: the role of the IGFreceptor signaling pathway. J Cell Physiol. 2009;220(2):485-91.

167. Longato L, de la Monte S, Kuzushita N, Horimoto M, Rogers AB, Slagle $\mathrm{BL}$, et al. Overexpression of insulin receptor substrate-1 and hepatitis Bx genes causes premalignant alterations in the liver. Hepatology. 2009:49(6):1935-43.

168. Villadsen SB, Bramsen JB, Ostenfeld MS, Wiklund ED, Fristrup N, Gao S, et al. The miR-143/-145 cluster regulates plasminogen activator inhibitor-1 in bladder cancer. Br J Cancer. 2012;106(2):366-74.

169. Peschiaroli A, Giacobbe A, Formosa A, Markert EK, Bongiorno-Borbone $\mathrm{L}$, Levine AJ, et al. miR-143 regulates hexokinase 2 expression in cancer cells. Oncogene. 2013;32(6):797-802

170. Yoshino H, Enokida H, Itesako T, Kojima S, Kinoshita T, Tatarano S, et al. Tumor-suppressive microRNA-143/145 cluster targets hexokinase-2 in renal cell carcinoma. Cancer Sci. 2013;104(12):1567-74.

171. Li C, Liu Y, Liu J, Chen Y, Li Z, Chen X, et al. Rapamycin inhibits human glioma cell proliferation through downregulating mTOR pathway and upregulating microRNA-143. Head Neck Oncol. 2012;4(3):66

172. Zhao S, Liu H, Liu Y, Wu J, Wang C, Hou X, et al. miR-143 inhibits glycolysis and depletes stemness of glioblastoma stem-like cells. Cancer Lett. 2013;333(2):253-60.

173. Yin Y, Yan ZP, Lu NN, Xu Q, He J, Qian X, et al. Downregulation of miR-145 associated with cancer progression and VEGF transcriptional activation by targeting N-RAS and IRS1. Biochim Biophys Acta. 2013;1829(2):239-47.

174. Lin T, Dong W, Huang J, Pan Q, Fan X, Zhang C, et al. MicroRNA-143 as a tumor suppressor for bladder cancer. J Urol. 2009;181(3):1372-80.

175. Yan X, Chen X, Liang H, Deng T, Chen W, Zhang S, et al. miR-143 and miR-145 synergistically regulate ERBB3 to suppress cell proliferation and invasion in breast cancer. Mol Cancer. 2014;13:220.

176. Yao N, Lu CL, Zhao JJ, Xia HF, Sun DG, Shi XQ, et al. A network of miRNAs expressed in the ovary are regulated by FSH. Front Biosci (Landmark Ed). 2009;14:3239-45.

177. Iio A, Takagi T, Miki K, Naoe T, Nakayama A, Akao Y. DDX6 posttranscriptionally down-regulates miR-143/145 expression through host gene NCR143/145 in cancer cells. Biochim Biophys Acta. 2013:1829(10):1102-10. 